\title{
Hume on Testimony Revisited
}

\author{
Axel Gelfert, National University of Singapore
}

\begin{abstract}
Among contemporary epistemologists of testimony, David Hume is standardly regarded as a 'global reductionist', where global reductionism requires the hearer to have sufficient first-hand knowledge of the facts in order to individually ascertain the reliability of the testimony in question. In the present paper, I argue that, by construing Hume's reductionism in too individualistic a fashion, the received view of Hume on testimony is inaccurate at best, and misleading at worst. Overall, Hume is much more willing to regard testimonial acceptance as a natural (default) response to testimony than has traditionally been thought. In particular, Hume believes that indirect evidence of human nature and of the social world around us, can take the place of first-hand evidence of the track record of individual speakers or specific classes of testimony. In developing this interpretation of Hume's views on testimony, the present paper draws on discussions found in the Treatise, the Enquiry, and in Hume's writings on historical knowledge.
\end{abstract}

In der zeitgenössischen Debatte um den erkenntnistheoretischen Status zeugnisbasierten Wissens wird gern auf David Hume als den Urheber eines „globalen Reduktionismus" verwiesen, demzufolge der Zeugnisempfänger über ausreichend empirische Belege für die Verlässlichkeit des betreffenden Zeugnisses verfügen muss. Im vorliegenden Aufsatz soll gezeigt werden, dass die in der Literatur vorherrschende Meinung ein übertrieben „individualistisches“ Bild von Humes Reduktionismus zeichnet; dadurch wird Humes Position in der gegenwärtigen Debatte ungenau und bisweilen irreführend wiedergegeben. Bei genauerer Betrachtung erweist sich Hume als ausgesprochen aufgeschlossen gegenüber dem Akzeptieren fremden Zeugnisses und sieht darin eine Art Grundmuster im testimonialen Umgang mit anderen. Insbesondere konzediert Hume, dass indirekt erworbenes Wissen um die menschliche Natur und die soziale Welt an die Stelle direkter Belege für die Verlässlichkeit einzelner Zeugen (oder bestimmter Klassen von Berichten) treten kann. Die im vorliegenden Aufsatz entwickelte Neuinterpretation stützt sich, neben der Treatise und der Enquiry, unter anderem auf Humes Schriften zum Problem der historischen Erkenntnis.

\section{Introduction}

In this paper, I develop an alternative interpretation of Hume's views on testimony as a source of knowledge. In contemporary discussions of the epistemic status of testimony-based beliefs, David Hume is typically cast in the role of 'global reductionist', who demands that each of us must have first-hand, non-testimonial evidence of the reliability of (relevant reference classes of) testimony, before accepting any new instance of it. Most contemporary epistemologists of 
testimony - reductionists and anti-reductionists alike - have taken it for granted that this is Hume's position. In the present paper, I shall argue that this is not a faithful representation of Hume's actual views regarding our reliance on others for knowledge; instead, he holds a nuanced position which is far more amenable to acceptance of testimony than has traditionally been thought.

The rest of this paper is organised into four sections. The first summarises the received view of Hume on testimony and analyses in more detail the reductionist commitments that are typically imputed to Hume. The second discusses an influential anti-reductionist critique, by C.A.J. Coady (1973 \& 1992), of Humean reductionism, and three recent responses to Coady's characterisation of Hume's position. This is followed by a section that traces the received view to a biased reception of Hume's famous discussion in his essay 'Of Miracles'. In this essay, Hume argues for a categorical rejection of 'miraculous' testimony (i.e., of alleged miracles). However, this stance does not, and is not intended by Hume to, extend to cases of everyday testimony. In particular, I offer three arguments - two based on textual evidence, and the third based on Hume's understanding of reduction as to why Hume's position is more favourable to testimonial acceptance than the received view would have us believe. The final section extends this picture by relating the issue of testimony to Hume's discussion, in the Treatise and elsewhere, of historical knowledge and our knowledge of human nature. I conclude by identifying points of convergence and divergence between my interpretation of Hume and positions within contemporary analytic epistemology of testimony.

\section{Hume's reductionism: the received view}

Contemporary discussions of the epistemology of testimony typically construe the debate as taking place between two schools of thought: anti-reductionism (also known variously as credulism or fundamentalism) and reductionism (or anticredulism) about the epistemic justification of testimony-based beliefs. On the one side there are those who argue that, all else being equal, we are entitled to accept a piece of testimony 'as is', without any obligation to take active steps in order to determine its veracity. On this (anti-reductionist) account, we have a default entitlement to believe what we are told. On the other side, one finds proponents of the idea that - given that testimony depends both on sense perception (for its reception) and on the sincerity and competence of the testifier (for its truthfulness) - whatever justification testimonial beliefs might have must be derived from, and must eventually be reducible to, more basic epistemic sources, such as perception, memory, and inference.

Often, this standard way of introducing the main issues in contemporary epistemology of testimony is prefaced with a sketch of two historical positions which - it is claimed - map rather well onto these two antagonistic 'temperaments', of reductionism and credulism, respectively. ${ }^{1}$ On the credulist side, one finds

\footnotetext{
1 For a discussion of an alternative strand in the historical development of the epistemology of testimony, see (Gelfert 2010).
} 
Thomas Reid, who believed testimonial exchanges to be governed by two principles 'implanted in our natures' by 'the wise and beneficent Author of Nature, who intended that we should be social creatures': the Principle of Veracity, according to which humans share 'the propensity to speak truth', and the Principle of Credulity, according to which we have a propensity to believe what we are told. (Reid 1764, VI: xxiv) The fact that these two principles 'tally with each other' is what justifies our practice of relying on what others tell us, or so Reid argues. On the opposing (anti-credulist) side, one inevitably finds David Hume cast in the role of archreductionist, thanks not least to his insistence that 'the reason why we place any credit in witnesses and historians, is not derived from any connexion, which we perceive a priori, between testimony and reality, but because we are accustomed to find a conformity between them' (EHU 10.8, 85). The idea seems to be that testimony 'should only be accepted if we are able to check that our informants have been reliable in the past', which is indeed how contemporary introductory texts typically portray Hume's views on testimony (Bailey \& O'Brien 2006, 140). Hume's strong reductionism appears to be mitigated somewhat by his simultaneous acknowledgment that 'there is no species of reasoning more common, more useful, and even necessary to human life, than that which is derived from the testimony of men' (EHU 10.5, 84); but this only goes to show that acceptance of testimony must be based on inferential reasoning from the speaker's track record and the plausibility of the claim to the acceptability of the specific testimonial claim in question. ${ }^{2}$

On the received view, Hume assimilates testimony, in a wholesale fashion, to other forms of inferential knowledge based on experience, such as knowledge of cause and effect: 'It being a general maxim, that no objects can have any discoverable connexion together, and that all the inferences, which we can draw from one another, are founded merely on our experience of their constant and regular conjunction; it is evident, that we ought not to make an exception to this maxim in favour of human testimony, whose connexion with any event seems, in itself, as little necessary as any other.' (EHU 10.5, 85) Since, in general, there is nothing in an instance of telling that necessitates the truth of what is told, our only grounds for relying on testimony are of an inductive nature. As Peter Lipton characterises Hume's position, 'any warrant we have for believing a particular piece of testimony must rest on some sort of enumerative induction.' (Lipton $1998,15)$ In the absence of sufficient inductive grounds, testimony cannot be a source of justified belief, let alone of knowledge: 'I should only believe what someone says if I know that they have a good track record, that is, if I know that they have reliably told the truth before.' (Bailey \& O'Brien 2006, 139)

Hume, in the following passage, appears to hint at how one might go about performing the relevant enumerative inductions:

\footnotetext{
${ }^{2}$ This is intended as the summary of a view that I shall be criticising later in this paper. That something is amiss with this interpretation of Hume is already suggested by the misconstrual of Hume's term 'species of reasoning' as a form of (conscious or deliberate) 'inferential reasoning': after all, Hume also describes the way we associate causes with effects as 'a true species of reasoning' (THN 1.3.7.5, $67)$, even when the latter is effortless and comes naturally.
} 
And as the evidence, derived from witnesses and human testimony, is founded on past experience, so it varies with the experience, and is regarded either as a proof or a probability, according as the conjunction between any particular kind of report and any kind of object has been found to be constant or variable. (EHU 10.6, 85)

Where the conformity between fact and testimony has been constant and unalterable (as judged by the reference class of 'kind of report' or 'kind of object'), we have proof; where it has not been, we only have 'what we properly call probability' (EHU 10.4, 84). Given that, for Hume, all probability 'supposes an opposition of experiments and observations' (ibid.), whenever we are faced with testimony that is at best probable, we must actively establish - through observations and gathering of evidence - the track record of the testifier and the reliability of the report in question. As C.A.J. Coady summarises the Reductionist Thesis (RT) he attributes to Hume:

We rely upon testimony as a species of evidence because each of us observes for himself a constant and regular conjunction between what people report and the way the world is. More particularly, we each observe for ourselves a constant conjunction between kinds of report and kinds of situation so that we have good inductive grounds for expecting this conjunction to continue in the future. (Coady 1992, 82)

Hence, while Hume recognises the usefulness of testimony, as well as its ineliminability, he regards testimony-based beliefs as lacking a rational basis, unless one has inferred - on the basis of an enumerative induction (either in terms of 'kinds of report' or 'kinds of situation') - that the testifier is reliable and his report credible. Hume's reductionist credentials lie in his commitment to the thesis (RT), along with his demand 'that you ought only to believe a person's claim to have observed a particular situation if that claim-situation pair is an instance of a generalisation linking types of claims with types of situations, where you have independently observed many other instances' (Lipton 1992, 14).

I shall call what I have described in the present section 'the received view' of Hume's account of testimony, since most contributors to the contemporary debate have accepted it, largely unreflectively, as a by and large accurate portrayal of Hume's views. ${ }^{3}$ Hence, reductionists about testimonial justification have found it necessary to distinguish their own brand of 'local reductionism' from Hume's alleged 'global reductionism' (Fricker 1994), whereas anti-reductionists have taken heart from the failure of Hume's reductionist project, which they regard as either 'viciously circular' or 'plainly false' (Coady 1992, $81 \mathrm{f}$.). However, as I shall argue in the following sections, as a representation of Hume's views on testimony, the received view is inaccurate at best, and seriously misleading at worst.

\footnotetext{
3 Among the few authors who have challenged this view are Faulkner (1998), Welbourne (2002), and Pitson (2006).
} 


\section{Coady's Hume and his critics}

Recent years have seen a continuing surge of interest in epistemological issues concerning testimony. While - contra the folkloristic self-image of contemporary epistemology of testimony - there has always been some interest in the topic throughout 20th-century analytic philosophy, much of the recent expansion can be attributed to the publication of Coady's 1992 monograph on the topic, which advocated a form of anti-reductionism, thereby sparking a number of responses (Fricker 1995, Lipton 1998). While Coady's intention is not primarily historical, he does develop his anti-reductionist position as a direct response to what he regards as Hume's position, where his construal of the latter largely coincides with the received view described in the previous section.

Specifically, Coady attacks Hume on three fronts. First, he argues that Humean reductionism is untenable in the light of the scarcity of first-hand evidence. We simply do not have at our disposal the kind of first-hand evidence that would be required to establish the conformity 'between testimony and reality', which, for Hume, must be the basis of all testimonial justification. Given the diversity of reports and testifiers we encounter daily, the task of establishing a sufficient enumerative induction for each 'kind of report', or 'kind of situation', would simply overwhelm us. Hume, according to Coady $(1992,80)$, is guilty of a vicious circle when, in an apparent effort to broaden the inductive base, he fudges the distinction between individual and communal observation by appealing to 'our experience of their constant and regular conjunction' (quoted after Coady 1992, 80). Such an appeal to communal experience must surely be illegitimate, given that the experiences of others are available to us only on the basis of their testimony and it is just such reliance on the testimony of others that the reductionist wanted to justify in the first place.

Coady's second attack concerns the very nature of the enumerative inductions envisaged. Given that, on the received view, the Humean reductionist must assess the credibility of a given piece of testimony by generalising from past instances - of reports, situations, or testifiers - of the same kind, one may very well worry whether it is at all feasible to classify instances of testimony into meaningful reference classes, upon which such enumerative induction can then be performed. Even prima facie intuitive classifications, for example by distinguishing between expert testimony and the testimony of laypersons, appear to be unavailable to the thoroughgoing reductionist, given that whether or not somebody is an expert is not typically something that we can ascertain on the basis of direct observation (Lipton 1998, 16). Coady's final argument against Hume concerns what one might call the 'massive error' hypothesis. When Hume claims that there is no connection we can perceive a priori between testimony and reality, and that reliance on testimony must instead be grounded in direct personal experience of the constant and regular conformity of testimony to reality, he implicitly presupposes - according to Coady - that it is at least possible that there is no correlation whatsoever between testimony and the facts. But such a possibility, Coady claims, is incompatible with the existence of a public language: 'On my construal of Hume's programme, his argument is defeated if to understand a language requires the admission of only 
one true report expressed in it.' (Coady 1992, 152) This last argument, however, seems to get the motivation for reductionism backwards, since the reductionist may very well want to grant that most of our testimony is true - as, indeed, Hume himself appears to concede when he speaks of the unparalleled usefulness of testimony - and yet may still attempt a reductionist justification in each case of testimony.

Here, I shall not take issue with Coady's defence, per se, of anti-reductionism, nor shall I have much to say about the second and third steps of his argument against Hume, which have been rebutted elsewhere in the literature (see Lyons 1997, Lipton 1998). Instead, I shall focus on the accuracy of Coady's characterisation of Hume's views on testimony. Given the prominent place he accords Hume in his 1992 monograph, it seems fair to credit Coady with being at least partially responsible for what I earlier called 'the received view' of Hume's account of testimony. It should also come as no surprise that Coady's reconstruction of Hume's views has come under close scrutiny by several recent authors (e.g. Traiger 1993; Hribek 1996; Faulkner 1998; Welbourne 2002). What emerges from those discussions is a more nuanced picture of Hume's views on testimony, not all aspects of which cohere with - and some of which contradict outright - the individualistically construed reductionist thesis (RT), according to which 'we rely upon testimony as a species of evidence because each of us observes for himself a constant and regular conjunction between what people report and the way the world is' (Coady 1992, 82).

In the interest of fairness, one should note that Coady does not claim that (RT), or an equivalent statement of the reductionist thesis, can be found directly in Hume's texts; it is, after all, a reconstruction of Hume's views, and Coady says as much when he introduces his formulation of (RT) with the words 'a Humean version of [the reductionist thesis] would run something like this ...' (Coady 1992,82 ) However, one way to check the plausibility of one's reconstructions of an author's views is to compare it with statements of similar standing elsewhere in his work. As Tomas Hribek argues (Hribek 1996, 190f.), such a comparison yields several instances where one finds a tension with the extreme individualism that is alleged in (RT). If testimony is to be vindicated as a 'useful species of reasoning', then reduction along the lines of (RT) must be possible. However, given the strong individualistic flavour of (RT), any belief in the success of our justifying the reports of testimony by reducing them to the allegedly indubitable utterances of the private observer' (Hribek 1996, 192), would seem to be in tension with Hume's rejection elsewhere of such optimism (e.g., when it comes to reducing talk of public objects to the first-person perspective). Indeed, it seems entirely plausible to model human sense perception after the case of human testimony, rather than vice versa. This, at least, seems to be how Annette Baier conceives of Hume's account of sense perception, when she writes:

As we sort out how reliable human testimony is, in particular matters, and in particular conditions, by checking it against other testimony that we have already checked, as well as against our own sense perceptions, so we check our senses' veracity against other already accepted sensory data, both our own and that of others whose testimony we trust. (Baier 1991, 119) 
One need not follow Baier in attributing to Hume an account of sense perception that is modelled after human testimony, in order to question why Hume should be committed to an 'eliminativist' form of reductionism that has no place for testimony as an independent source of knowledge. Recall that Hume merely demands that no exception be made in favour of testimony, when it comes to drawing inferences on its basis; in this respect, testimony is entirely on a par with direct personal experience, in that inferences must be founded 'on our experience of their constant and regular conjunction'.

As Michael Welbourne rightly points out, one must be careful 'not to be misled by this word inference, which Hume uses to designate 'any rule-governed passage of mind from input to output' (Welbourne 2002, 412), without necessarily implying the presence of 'conscious explicit reasoning' (ibid.). ${ }^{4}$ Indeed, this gives rise to another criticism against Coady's attribution of the reductionist thesis (RT) to Hume. For, (RT) seems to suggest that the acquisition of inductive grounds is a two-step process, consisting of, first, the gathering of first-hand evidence of 'a constant and regular conjunction between what people report and the way the world is' and, second, a conscious, reasoned inference to the reliability of a given piece of testimony. But this is an overly intellectualized picture of what goes on in testimonial acceptance, and Hume, with his broadly naturalistic account of human psychology and belief formation, need not be committed to such an account. As Welbourne points out, there are passages in Hume's writing, which suggest that he 'clearly sees that our propensity to accept what we are told is not something which bears, externally, as it were, on the way we deal with testimonies', but is something that comes naturally as the 'default response' to our understanding the speech-act of telling for what it is (Welbourne 2002, 416). One such passage concerns the different responses that are naturally elicited in contexts of informative speech as opposed to, say, mere story-telling:

If one person sits down to read a book as a romance, and another as a true history, they plainly receive the same ideas, and in the same order; nor does the incredulity of the one, and the belief of the other, hinder them from putting the very same sense upon their author. (THN 1.3.7.7, 68)

As Welbourne sees it, Hume 'takes it unreflectively, as a manifest given, that there is a family of speech-acts such as informing and reporting, which by their nature look for the acceptance of proffered information on the part of their auditors' (Welbourne 2002, 418). Hence, in his attribution of an individualistically construed reductionist thesis along the lines of (RT), Coady is in effect ascribing to Hume an over-complex view of testimonial acceptance. Neither when we initially acquire a shared language, nor when we later in life accept a piece of testimony, do we need to 'learn two separate lessons', as it were: 'on the one hand, what it is to tell someone [...], on the other hand, what sort of response is normal for an act of informative telling.' (Welbourne 2002, 418) In much the same way that Hume believes that 'the intercourse of sentiments [...], in society

\footnotetext{
${ }^{4}$ See also fn. 2 in the present paper; on the character of Hume's conception of reasoning, see (Owen 1999).
} 
and conversations, makes us form some general inalterable standard, by which we may approve or disapprove of characters or manners' (THN 3.3.3.2, 385), we approve or disapprove of testimony according to standards we have acquired naturally, on the basis of experience. Saul Traiger puts this nicely, when he writes: 'Hume thinks that experience is our guide in causal inference, and his point is that experience informs our inferences about testimony just as it does our testimonyfree inferences.' (Traiger 1993, 144)

\section{Beyond 'Of Miracles'}

Before giving a more comprehensive account of Hume's views on testimony, it is worth reflecting on what might have given rise to the received view I am criticising. Apart from the strategic consideration that individualistically construed reductionism may serve as a convenient foil for anti-reductionist proposals, which appear more attractive and plausible by comparison, there are further reasons, to do with a certain selectivity in reading Hume on testimony. Much of Hume's discussion is found in his essay 'Of Miracles' (Section 10 of the Enquiry), in which he argues for categorical rejection as the only rational response to alleged miracles. Much ink has been spilt on whether or not Hume's argument against miracles is successful (see Fogelin 2003 and Earman 2000 for two contrasting views), and in the present paper I shall have nothing to add to this debate. Instead, I intend to look past the issue of miracles and argue that the focus on miraculous testimony, throughout much of the debate, has obscured Hume's views on testimony in general.

Hume's rejection of testimony-based belief in miracles goes something like this: Since a miracle is defined as 'a violation of the laws of nature' (EHU 10.12, 86), yet such laws of nature are established through 'firm and unalterable experience' (ibid.), hence when we encounter a piece of miraculous testimony, we must always weigh the probability of the testimony of witnesses - who, as human beings, are known to be fallible - against the possibility of a violation of the laws of nature. But since the evidence for the laws of nature amount to proof, in virtue of their being supported by 'firm and unalterable experience', such a comparison will always come down against the (merely probable) testimony in question. Miraculous testimony - qua being testimony, one might argue - has, it seems, maneuvered itself into an untenable position. However, what really undermines miraculous testimony is not its status of testimony as such; rather, it is the mismatch between what testimony can do - namely, serve as a fallible source of knowledge - and what the specific content of miraculous testimony demands, viz. certainty that amounts to proof. Now, it is easy to see how Hume's negative stance towards miraculous testimony might have come to be equated with a rejection, more generally, of testimony as a source of knowledge. Such an inference from the special case of testimony about miracles to testimony in general, however, is quite mistaken, since it conflates the relative inadequacy of testimony for proving alleged 'violations of the laws of nature' with the epistemic merits of testimony considered in its own right, i.e. as a source of probable knowledge. There are sev- 
eral reasons why, upon closer inspection, Hume's argument against miraculous testimony appears, in fact, much more favourable to everyday cases of testimony than has commonly been assumed. In the remainder of this section, I shall discuss three such reasons, which are either supported by direct textual evidence or are strongly suggested by the structure of his argument.

First, I want to argue that Hume rules out miraculous testimony on the basis of specific features of the content of the testimony in question, rather than on the basis of failures of the institution of testimony as such. Hence, the specific shortcomings of miraculous testimony are not representative of the large class of ordinary beliefs we justifiedly acquire on the basis of everyday testimony. In the first part of his two-part essay 'Of Miracles', Hume argues against testimonybased belief in miracles, on the grounds outlined in the previous paragraph. Given that Hume, in this part of his essay, draws mainly on conceptual aspects of probability and proof and their relation to alleged exceptions to the laws of nature, one might perhaps expect to find a more direct discussion of testimonial failures in general (e.g., due to insincerity or incompetence on the part of the testifier) in the second part of his essay, in which Hume aims to show that the actual historical testimony we have for miracles has never come close to constituting proof of the events reported, thus invalidating miraculous testimony as a rational basis for (Christian) religion. One might well expect Hume to call into question the credibility, sincerity, or competence of the witnesses that were involved in the various historical cases he discusses, thereby casting doubt on the reliability of testimony in general. Interestingly, he does little of this sort. Instead, he goes to great length to argue that several of the testifiers in question exhibit 'gravity', 'solidity', 'probity', 'candour', 'veracity', 'unquestioned intergrity', and other fine epistemic characteristics. Hume's point, then, seems to be that we are to reject miraculous testimony as evidence, even when we receive it from reputable witnesses, because any 'just reasoner' will conclude 'that such an evidence carrie[s] falsehood upon the very face of $i t$, and that a miracle, supported by the human testimony, [is] more properly a subject of derision than of argument' (EHU 10.26, 93; my italics). Hume, in Part I of his essay, argues that allegations of miracles are to be categorically rejected, because such testimony gives us merely probable grounds for belief, when the content of what is said (i.e., the alleged violation of the laws of nature) demands proof. In an analogous move, Part II argues that no actual miraculous testimony, even when related by the most respectable historians and witnesses, has ever constituted good grounds for belief in miracles, because, in addition to their historically originating from 'barbarous and ignorant people', by their very content such miraculous reports were on a par with those 'forged miracles, and prophecies, and supernatural events, which, in all ages, [...] prove sufficiently the strong propensity of mankind to the extraordinary and the marvellous, and ought reasonably to beget a suspicion against all relations of this kind' (EHU 10.19, 89).

The second argument I wish to discuss concerns a structural feature of Hume's discussion in 'Of Miracles'. At several crucial steps in his presentation, Hume discusses cases of conflicting testimonies. Sometimes, the role of such conflicts is destructive only, most notably in the case of the competing miraculous testi- 
monies of different religions. Hence, comparing the miracles 'of all the authors and witnesses, Grecian, Chinese, and Roman Catholic' with, for example, the miracles 'of Mahomet or his successors', Hume argues that 'we are to regard their testimony in the same light as if they had mentioned that Mahometan miracle, and had in express terms contradicted it, with the same certainty as they have for the miracle they relate' (EHU 10.24, 92). In other words, in contradicting each other and in sometimes actively disputing another religious tradition's miraculous claims, each religion undermines the rational basis for belief in its own founding miracles. But such "mutually assured destruction" need not always be the outcome of conflicting testimonies. In such cases where a fact is 'attested by a sufficient number of men' (EHU 10.15, 88), the unanimous testimony of a group of independent witnesses, may well outweigh an isolated dissenting voice. This, I want to suggest, is precisely what is behind Hume's application of the general idea that 'a wise man [...] proportions his belief to the evidence', to the specific case of 'contrariety of evidence', where such contrariety, in the case of testimony, 'may be derived from several different causes: from the opposition of contrary testimony; from the character or number of witnesses; from the manner of their delivering their testimony; or from the union of all these circumstances' (EHU 10.7, 85). Tony Pitson makes a similar point when he argues that, in such a situation, the wise man is faced with what Hume calls 'a contest of two opposite experiences':

one which favours acceptance of the testimony he is offered, and another which speaks against the content of that testimony. But in neither case is experience simply a matter of the individual's own observations; for it also reflects the process by which the experiences of others have been assimilated. (Pitson 2006, 9f.)

Moreover, I want to suggest that, on this reading, it is possible to resolve an often-noted tension in Hume's presentation of his case. Critics of Humean 'reductionism', and Coady in particular, have pointed out that Hume himself falls back into the 'natural' - i.e., anti-reductionist - way of thinking about testimony when he helps himself to first-person plural locutions such as 'our experience of their constant and regular conjunction' (EHU 10.5, 84; italics added), or when he claims that a dead man's coming back to life 'has never been observed in any age or country' (EHU 10.12, 87; italics added). After all, such knowledge could only be granted if one already accepts the validity of testimony as a source of knowledge. However, on the interpretation I am suggesting, Hume is not guilty of self-contradiction in his use of the first-person plural. First, given Hume's emphasis, in the second part of his essay, on the dubious historical origins of (actual) miraculous reports, the first-person plural 'we' may be understood in the exclusive sense, contrasting the scientifically informed observational reports of Hume and his enlightened contemporaries with those of the 'barbarous and ignorant people', who uncritically accepted miraculous reports and perhaps even embellished them. Second, and more importantly, if experience can be 'pooled' in the way Pitson suggests - by accepting plausible, uncontradicted testimony and assimilating it to one's own experience, with which it coheres - then Hume need not be committed to any strong individualistic form of reductionism in the first 
place, and his invocation of the communal 'we', contra Coady, does not constitute a self-contradiction on his part.

As a third argument in support of a more moderate interpretation of Hume's reductionism, I wish to question the received view of what a successful reduction would amount to in the first place. Again, it will be instructive to turn to Coady's thesis (RT) for a concise statement of the received view on this matter. On this view, Hume demands that 'we rely upon testimony as a species of evidence because each of us observes for himself a constant and regular conjunction between what people report and the way the world is' (Coady 1992, 82). This formulation of (RT), in conjunction with the standard objection, discussed earlier, that such enumerative inductions are inevitably afflicted by reference class problems, suggests that a successful instance of establishing the requisite conformity between testimony and reality would consist in checking a given piece of testimony against whatever fact it purports to report. In other words, we seek to gain direct experience of the state of affairs in question; if it corresponds to the report, then all is well, whereas if it differs in relevant ways, we have proven the report wrong, and the reporter's track record suffers a glitch. This, however, is not how Hume thinks we should assess the testimony we receive. To be sure, whenever 'the conjunction between any particular kind of report and any kind of object' has been found to be 'variable', 'the ultimate standard, by which we determine all disputes, that may arise concerning them, is always derived from experience and observation' (EHU 10.6, 85). But precisely because such cases have already been empirically found to exhibit non-constancy, further empirical investigation - by comparing testimonies directly with the facts in question - will not settle the matter. Note also that, when Hume speaks of the 'ultimate standard' being always 'derived from experience and observation', he refers to experience and observation in a wholesale manner, as global sources of knowledge; he clearly does not envisage that we should undertake the Sisyphean task of settling all empirical disputes through first-hand ascertaining of the facts. What Hume does have in mind, is evident from his analysis, a little earlier, of what it would take to place trust in testimony:

\footnotetext{
Were not the memory tenacious to a certain degree; had not men commonly an inclination to truth and a principle of probity; were they not sensible to shame, when detected in a falsehood: were not these, I say, discovered by experience to be qualities, inherent in human nature, we should never repose the least confidence in human testimony. (EHU 10.5, 85; italics added)
}

It is clear, then, that Hume is not committed to a narrow reductionist thesis, according to which each of us, before accepting a new piece of testimony, must individually establish that testimonies in a given reference class correspond to the facts; instead, he allows for indirect evidence, both of aspects of human nature ('an inclination to truth') and of social pressures ('shame when detected in a falsehood'), to take the place of direct comparison of testimony with the facts. It is such general knowledge of human nature and the social world - for example, the presence of standards of accuracy and truthfulness in the society we find ourselves in - that must be 'derived from experience and observation'. Often enough, 
the requisite knowledge will be acquired tacitly, simply through immersion in the social world; in this sense, the success of practices that depend on the giving and receiving of testimony may well form part of the justification of our relying on testimony in any individual instance. When understood in this way, what might at first seem a formidable task for any one person - namely, acquiring sufficient evidence, on the basis of experience and observation, of the reliability of testimony upon closer inspection appears a lot more manageable, and certainly more realistic than the excessive demands associated with individualistic reductionism, as described by (RT).

\section{Testimony, history, and human nature}

A more complete picture of Hume's views on testimony must take into account his discussion not just in 'Of Miracles', but also in the Treatise. Closer inspection of what Hume has to say in the Treatise, for example on the acquisition of historical knowledge, gives further substance to the interpretation developed in the previous section in response to the received view. Here, I shall focus on three points I emphasised earlier, each of which is supported by aspects of Hume's discussion in the Treatise.

First, recall Welbourne's contention that Hume takes it 'as a manifest given' that certain speech acts 'by their nature look for the acceptance of proffered information on the part of their auditors' (Welbourne 2002, 418); testimonial acceptance, for Hume, is one of the natural responses available to us upon encountering speech-acts of informing and reporting. Even before he turns to questions of belief and justification in general, Hume, in the Treatise, discusses an example of testimonial knowledge, when, in the section 'Of the component parts of our reasoning concerning cause and effect', he explains the causal process by which we acquire historical beliefs - e.g., the belief 'that Caesar was kill'd in the senatehouse on the ides of March' - from impressions of the 'characters and letters' on the printed pages of historical treatises:

Here are certain characters and letters present either to our memory or senses; which characters we likewise remember to have been used as the signs of certain ideas; and these ideas were either in the minds of such as were immediately present at that action, and received the ideas directly from its existence; or they were derived from the testimony of others, and that again from another testimony, by a visible gradation, till we arrive at those who were eye-witnesses and spectators of the event. (THN 1.3.4.2, 58)

It might seem, and indeed it has been argued (Anscombe 1973), that Hume is here giving an account of how we are to justify testimonial beliefs, by inferentially tracing them back - along the chain of testimonial transmission, as it were to their origins in the impressions and ideas of eye-witnesses. But, as Traiger argues, such an interpretation would misunderstand the context of the example: the passage just quoted is immediately preceded by Hume's argument 'that a man who sees "the remains of pompous buildings", could not infer the prior 
existence of a civilization unless he had "perused volumes" of ancient history or had received testimony after some fashion' (Traiger 1993, 141). The spectator here would not regard the structures around him as visual evidence of an ancient civilization, if he did not already hold the belief that 'there is a historical chain from witnesses, through testimony, to the existence of the civilization whose remains [he] is now viewing' (ibid.). A similar point can now be made for the case of historical testimony that is related to us through the 'characters and letters' on a printed page. Such printed testimony - like all testimony - must be received in the spirit in which it is given, i.e. must be recognised as informative testimony (and not, say, fiction, as in Welbourne's example of how one may treat the 'events' recounted in a novel) before it can merit belief. However, once so recognised, its content becomes directly available to us, and the testimony as a whole may be assessed in accordance with the general maxims by which we 'proportion our belief to the evidence'; beyond such general assessment, there is no obligation on our part to inferentially reconstruct the series of events that led up to our encountering the testimony in question.

Second, Hume's philosophy of history also sheds light on another point discussed earlier. In his essay 'Of the Study of History', first published in 1742, though dropped from later editions of his collected works, Hume writes that 'we should be for ever children in understanding', were it not for history 'which extends our experience to all past ages, and to the most distant nation' (Hume 1742, 531 f.). Hence,

A man acquainted with history may, in some respect, be said to have lived from the beginning of the world, and to have been making continual additions to his stock of knowledge in every country. (ibid.).

Experience, insofar as it underwrites knowledge of facts, on this account really can be 'pooled' in the sense suggested earlier by Pitson (and, to some degree, Baier). Of course, there is also a strict sense in which we can only 'have' our own experiences - we can only ever feel what our pain is like, not that of other people but this stricter sense is not what is required for claims to knowledge. Hence, Hume is not contradicting himself when he writes in a letter to the Reverend Blair:

No man can have any other experience but his own. The experience of others becomes his only by the credit which he gives to their testimony; which proceeds from his own experience of human nature. (quoted after Traiger 1993, 139)

But if experience can be 'pooled' for all epistemic intents and purposes, and if historical testimony is indeed, as Hume suggests, the exemplary case of how experience can come to be shared, then Hume's 'reductionist' demand - viz., that the 'ultimate standard' for all causal (including testimonial) inferences must lie in 'experience and observation' - seems much less radical than has been suggested by proponents of the received view and its individualistic thesis (RT).

Finally, for the last of my three observations in this section, I wish to elaborate on Hume's almost offhand remark, in the letter just quoted, to the Rev. Blair, that one's response to testimony 'proceeds from [one's] own experience of human nature'. Indeed, in the light of the discussion so far, this appears to be the crucial 
point for Hume. Recall that, in his essay 'Of Miracles', Hume asserts a counterpart of the same argument, when he argues that trust in testimony is dependent on our having 'discovered by experience' (rather than merely having posited as innate) certain 'qualities, inherent in human nature', such as an inclination to truthfulness, a sense of probity, and a susceptibility to social sanctions (such as a feeling of shame 'when detected in a falsehood'). An even stronger version of this sentiment may be found in the Treatise:

When we receive any matter of fact upon human testimony, our faith arises from the very same origin as our inferences from causes to effects, and from effects to causes; nor is there any thing but our experience of the governing principles of human nature, which can give us any assurance of the veracity of men. (THN 1.3.9.12, 78; second italics added)

Hume's appeal to the central role of human nature in justifying our actual and ineliminable reliance on the testimony of others, thus reduces considerably the burden of proof that the recipient of testimony must bear. No longer does the hearer face the Sisyphean task of assessing individual speakers' track records with respect to a plethora of possible reference classes, defined variously by 'kind of report' or 'kind of situation'. 5 Instead, when faced with an interlocutor's testimony, the hearer can draw on his background knowledge of human nature, as he typically will, as a matter of course, when he deploys the usual range of folk-psychological attitudes, for example by ascribing motivations and actions towards a speaker, based on past experience.

It is perhaps instructive to conclude by comparing the overall picture that emerges from this reconsideration of Hume's views on testimony with contemporary positions in analytic epistemology of testimony. Despite his acknowledgment of the ineliminability and usefulness of testimony as a source of knowledge, Hume is no adherent of credulism. In various places, he laments a widespread tendency to 'credulity, or a too easy faith in the testimony of others', even in such matters as 'apparitions, enchantments, and prodigies, however contrary to daily experience and observation' (THN 1.3.9.12, 78). Testimony, thus, needs to be regulated by the same kinds of maxims as experience in general. But regulating our reliance on testimony in ways that accord with reason and experience, does not require reducing testimonial knowledge to first-hand experience. While Hume is no credulist, he is no hard-line reductionist, either. His view, in fact, may be closest to what in contemporary epistemology of testimony has come to be known as local reductionism'. ${ }^{6}$ However, whereas Hume makes acceptance of testimony dependent on our background knowledge of human nature, local reductionism demands that the hearer should be 'continually evaluating' the speaker 'for trustworthiness throughout their exchange, in the light of the evidence, or cues, available to her'

\footnotetext{
${ }^{5}$ Paul Faulkner makes a similar point when he argues that, by emphasising the role of human nature, Hume simplifies the task of - roughly speaking - establishing 'the constancy of the conjunction between this type of testimony and the testified event', since 'this type' is now simply 'defined by our judgement of the speaker's nature' (Faulkner 1998, 307).

${ }^{6}$ Local reductionism has been developed most fully by Elizabeth Fricker. See (Fricker 1994; 1995); for a sustained critique of local reductionism, see (Gelfert 2009).
} 
(Fricker 1994, 150). Sometimes this may require constructing an 'explanatory mini-theory' of the speaker's behaviour (Fricker 1995, 404); at other times, we may have to scrutinise the speaker 'for any tell-tale signs revealing likely untrustworthiness' (Fricker 1994, 150). At first sight, such recommendations may seem not that far removed from Hume's injunction that the 'wise man' ought to 'proportion his belief to the evidence', where such evidence, as we have seen, may take various forms and may include further testimony. There also appears to be a close link between Hume, who bemoaned a 'too easy faith in the testimony of others', and local reductionism's most succinct rallying cry: 'Against Gullibility'. But there are also limits to the similarities: as we saw earlier, Hume dismisses gullibility primarily in the context of matters that are 'contrary to daily experience and observation' (THN 1.3.9.12, 78), and he does not share the local reductionist's concern with 'monitoring the speaker for any tell-tale signs revealing likely untrustworthiness' (Fricker 1994, 150) - at least not where this is thought to go beyond the general maxim, valid for all matters of experience, that we should 'proportion our belief to the evidence'. Indeed, the initial suggestion that Hume might be regarded as a local reductionist of sorts, may seem rather ironic, given that local reductionism was explicitly conceived as a response to 'hard-nosed' Humean reductionism. What further compounds the irony is that, all things considered, Hume appears to take a more optimistic view of human nature than some contemporary epistemologists. Whereas local reductionists have argued that 'we know too much about human nature to want to trust anyone, let alone everyone, uncritically' (Fricker 1995, 400), Hume appears to believe that our knowledge of human nature can assure us of our fellow human beings' probity and general 'inclination to truth'. It is perhaps a testament to the subtlety and depth of Hume's philosophical thinking that, even on a matter as seemingly clearcut as his views on testimony, he continues to be one step ahead of both his (anti-reductionist) critics and his (reductionist) 'false friends'. ${ }^{8}$

\section{References}

Anscombe, E. 1973. Hume and Julius Caesar. Analysis 34, 1-7.

Baier, A. 1991. A Progress of Sentiments, Cambridge (Mass.): Harvard University Press.

Bailey, A./O'Brien, D. 2006. Hume's Enquiry Concerning Human Understanding (Reader's Guide), London: Continuum.

Coady, C.A.J. 1973. Testimony and Observation. American Philosophical Quarterly 10, 149155.

Coady, C.A.J. 1992. Testimony. A Philosophical Study, Oxford: Oxford University Press.

Earman, J. 2000. Hume's Abject Failure. The Argument Against Miracles, Oxford: Oxford University Press.

\footnotetext{
${ }^{7}$ Thus the title of (Fricker 1994).

${ }^{8}$ I would like to thank Tamás Demeter for valuable comments on an earlier draft of this paper. This paper was written during a Visiting Research Fellowship at the Institute for Advanced Studies in the Humanities, University of Edinburgh. I am grateful to all members and staff of the Institute for their hospitality.
} 
Faulkner, P. 1998. David Hume's Reductionist Epistemology of Testimony. Pacific Philosophical Quarterly 79, 302-313.

Fogelin, R. 2003. A Defense of Hume on Miracles. Princeton: Princeton University Press.

Fricker, E. 1994. Against Gullibility. In: Matilal, B.K./Chakrabarti, A. (eds.). Knowing From Words, Dordrecht: Kluwer.

Fricker, E. 1995. Telling and Trusting. Reductionism and Anti-Reductionism in the Epistemology of Testimony. Mind 104, 393-411.

Gelfert, A. 2009. Indefensible Middle Ground For Local Reductionism About Testimony. Ratio 22, 170-190.

Gelfert, A. 2010. Kant and the Enlightenment's Contribution to Social Epistemology. Episteme 7, 79-99.

Hribek, T. 1996. Against Coady on Hume on Testimony. Acta Analytica 16, 189-200.

Hume, D. 1742. Of the Study of History. In: The Philosophical Works of David Hume (Vol. 4), 1826. Edinburgh: Black and Tait.

Lipton, P. 1998. The Epistemology of Testimony. Studies in History and Philosophy of Science 29, 1-31.

Lyons, J. 1997. Testimony, Induction, and Folk Psychology. Australasian Journal of Philosophy $75,163-178$.

Owen, D. 1999. Hume's Reason, Oxford: Oxford University Press.

Pitson, T. 2006. George Campbell's Critique of Hume on Testimony. The Journal of Scottish Philosophy 4, 1-15.

Reid, T. 1764. An Inquiry into the Human Mind, Brooks (ed.) 1997. Edinburgh: Edinburgh UP.

Traiger, S. 1993. Humean Testimony. Pacific Philosophical Quarterly 74, 135-149.

Welbourne, M. 2002. Is Hume Really a Reductivist? Studies in History and Philosophy of Science 33, 407-423.

\section{Works by David Hume}

EHU Hume, D. 1748. An Enquiry Concerning Human Understanding, Beauchamp (ed.) 2000. Oxford: Oxford University Press.

THN Hume, D. 1739-40. A Treatise of Human Nature, Norton/Norton (eds.) 2007. Oxford: Oxford University Press. 